\title{
EFEK GREEN PERCEIVED VALUE DAN RISK TERHADAP GREEN REPURCHASE INTENTION: GREEN TRUST SEBAGAI PEMEDIASI PADA PENGGUNA PERTALITE DI KOTA TERNATE
}

\author{
Ardhy La Mada \\ Universitas Khairun \\ Ida Hidayanti \\ Universitas Khairun \\ Ibnu Sina Hi. Yusuf \\ Universitas Khairun \\ ardhylamada1299@gmail.com \\ hidayanti.fekonunkhair@gmail.com
}

\begin{abstract}
Abstrak
Penelitian ini bertujuan untuk mengetahui pengaruh Green Perceived Value dan Green Perceived Risk terhadap Green Repurchase Intention, dengan Green Trut sebagai variabel mediasi. Penelitian ini merupakan penelitian kuantitatif. Populasi dalam penelitian ini meliputi masyarakat Kota Ternate yang menggunakan BBM jenis Pertalite pada kendaraan bermotor dengan metode pengambilan sampel yaitu Non Probability Sampling dan teknik pengambilan sampel adalah Purposive Sampling. Teknik analisis yang digunakan dalam penelitian ini adalah menggunakan analisis jalur, uji $\mathrm{F}$, uji t dan uji sobel dengan bantuan aplikasi IBM SPSS versi 26. Hasil penelitian ini menunjukkan bahwa: green perceived value berpengaruh positif dan signifikan terhadap green trust dan green repurchase intention, green perceived risk berpengaruh positif dan tidak signifikan terhadap green trust dan green perceived risk berpengaruh negatif dan tidak signifikan green repurchase intention, green trust berpengaruh positif dan signifikan terhadap green repurchase intention, green trust dapat memediasi pengaruh green perceived value ke green repurchase intention, green trust dapat memediasi pengaruh green perceived risk ke green repurchase intention.
\end{abstract}

Kata kunci: Green Perceived Value, Green Perceived Risk, Green Repurchase Intention, Green Trust

\section{Pendahuluan}

Masalah-masalah lingkungan sering terdengar di masyarakat contohnya adalah pemanasan global. pemanasan global merupakan peningkatan suhu di permukaan bumi, membuat tingginya permukaan air laut dan mengakibatkan lapisan ozon yang menipis. Dampak negatif yang ditimbulkan pemanasan global mendorong kepedulian masyarakat untuk lebih peduli terhadap lingkungan agar kualitas udara menjadi baik. Kualitas udara yang buruk tidak lepas dari polusi yang berasal dari aktivitas kegiatan manusia, seperti hasil dari manufaktur, transportasi, dan ketergantungan pada bahan bakar fosil.

Kendaraan bermotor dikatakan sebagai salah satu alat transportasi yang memerlukan mesin sebagai penggerak mulanya, baik untuk kendaraan roda dua maupun untuk kendaraan roda empat. Motor bakar merupakan salah satu mesin yang digunakan sebagai penggerak 
mula-mula alat transportasi. Motor bakar memiliki suatu mesin konversi energi yang merubah energi kalor menjadi energi mekanik. Dengan adanya energi kalor sebagai suatu penghasil tenaga maka sudah semestinya mesin tersebut memerlukan bahan bakar dan sistem pembakaran yang digunakan sebagai sumber kalor.

Adanya pertimbangan konsumen sebelum memutuskan untuk mengkonsumsi suatu produk yang dibutuhkan namun tetap juga menjaga kelestarian lingkungan, membuat perusahaan perlu menerapkan suatu konsep bisnis baru dengan menerapkan isu-isu mengenai keprihatinan terhadap kondisi lingkungan yang kemudian disebut green marketing. (Polonsky, 1994) mengatakan bahwa green marketing atau pemasaran lingkungan terdiri dari semua kegiatan yang dirancang untuk menghasilkan dan memfasilitasi transaksi yang dimaksudkan untuk memenuhi kebutuhan atau keinginan manusia, sehingga kepuasan terhadap kebutuhan dan keinginan ini dapat terjadi dengan dampak kerugian yang minimal pada lingkungan sekitar.

PT. Pertamina yang merupakan perusahaan penghasil bahan bakar minyak (BBM) di Indonesia. Program langit biru PT pertamina dan rencana penghapusan BBM jenis premium yang mulai diberlakukan pada tanggal 01 januari 2021 sesuai dengan peraturan pemerintah no.41 tahun 1999 tentang pengendalian pencemaran udara yang perlu menjadi perhatian seluruh pihak dalam upaya mengurangi pencemaran udara itu dapat dilakukan dengan melalui pengendalian emisi gas buang kendaraan bermotor salah satunya adalah dengan menggunakan BBM yang lebih berkualitas dan ramah lingkungan. BBM yang berkualitas itu tentu akan berdampak positif terhadap performa kendaraan serta lebih irit karena pembakaran diruang mesin itu lebih sempurna. Oleh karena itu pertamina terus mendorong penggunaan produk-produk BBM yang berkualitas seperti pertalite, pertamax dan pertamax turbo.

Pertalite merupakan Bahan bakar minyak (BBM) jenis baru yang diproduksi Pertamina, Jika dibandingkan dengan premium Pertalite memiliki kualitas bahan bakar lebih baik, sebab memiliki kadar Research Oktan Number (RON) 90, di atas Premium, yang hanya RON 88. Pertalite memiliki beberapa keunggulan dibandingkan dengan Premium. Pertalite direkomendasikan untuk kendaraan yang memiliki kompresi 9:1-10:1 dan mobil tahun 2000 ke atas, terutama yang telah menggunakan teknologi setara dengan Electronic Fuel Injection (EFI) dan catalytic converters (pengubah katalitik). Kota Ternate sendiri merupakan daerah dengan konsumsi bahan bakar minyak (BBM) jenis pertalite tertinggi di wilayah Provinsi Maluku Utara (MALUT). Penggunaan BBM jenis pertalite di Ternate permintaannya cukup tinggi, baik pengecer hingga Stasiun Pengisian Bahan Bakar Umum (SPBU). Sementara itu, Malut merupakan wilayah dengan konsumsi paling tinggi jenis BBM pertalite sehigga mecapai 50 persen.

Tabel 1. Daftar Harga BBM Serta Konsumsi Per Bulan Pertalite di Kota Ternate

\begin{tabular}{|c|c|c|}
\hline Jenis BBM & Konsumsi per Bulan & Harga \\
\hline Dexlite & 120.000 Kiloliter/ Bulan & Rp. 9.700/liter \\
\hline Pertamax & 138.000 Kiloliter/ Bulan & Rp. 9.200/liter \\
\hline Pertalite & 936.000 Kiloliter/ Bulan & Rp. 7.850/liter \\
\hline Premium & 0 & Rp. 6.450/liter \\
\hline
\end{tabular}

Sumber: SPBU di Kota Ternate (2021)

Keinginan membeli kembali mengacu pada penilaian individu tentang membeli lagi layanan yang ditunjuk dari perusahaan yang sama, dengan mempertimbangkan situasi saat ini dan berbagai kemungkinan (Lacey dan Morgan, 2008). Sedangkan menurut (Lam et al., 2016) green repurchase intention yaitu tindakan pembelian produk hijau dimana konsumen 
memberi respon positif terhadap kualitas produk yang ramah lingkungan dan berniat untuk melakukan pembelian kembali atau menggunakan kembali produk yang ramah lingkungan di perusahaan yang sama. Upaya yang dapat dilakukan untuk meningkatkan green repurchase intention yaitu dengan green perceived value, green perceived risk dan green trust. Green trust adalah keyakinan untuk bergantung pada produk, jasa, atau merek berdasarkan harapan akan kepercayaan, kebaikan, dan mutu pada kinerjanya terhadap lingkungan (Chen, 2010).

Peningkatan kepercayaan konsumen bisa dilakukan dengan memberikan kualitas produk yang lebih bagus. Persepsi kualitas adalah penilaian keunggulan dan kelebihan keseluruhan dari suatu produk atau pelayanan oleh pengguna (Chen et al., 2015). Peningkatan kualitas yang dirasakan tidak hanya untuk meningkatkan nilai kepuasan pelanggan tetapi juga meningkatkan nilai kepercayaan pelanggan. Kepercayaan juga dapat dipengaruhi oleh kepuasan, artinya apabila kepuasan yang dirasakan semakin tinggi maka kepercayaan terhadap suatu produk juga semakin meningkat (Wulansari dan Sri Suprapti, 2015). Pembelian konsumen terjadi apabila risiko yang dirasakan berkurang, maka dari itu kurangnya suatu risiko yang dirasakan bertujuan untuk meningkatan kepercayaan konsumen (Chang dan Chen, 2008). Maka dari itu, (Chen dan Chang, 2012) mendefinisikan green perceived risk sebagai Harapan negatif dari konsekuensi lingkungan yang terkait dengan perilaku pembelian, yang mana green perceived risk tersebut, akan berpengaruh secara negatif terhadap green trust.

Sesuai dengan pernyataan diatas, peneliti ingin membuktikan kembali variabel green perceived risk yang berpengaruh negatif terhadap green trust. Berdasarkan penelitian yang di lakukan oleh (Dewi dan Rastini, 2016) yang berjudul "Peran Green Trust Memediasi Green Perceived Value dan Green Perceived Risk Terhadap Green Repurchase Intention" pada konsumen The Face Shop di kota Denpasar, dan penelitian yang di lakukan oleh (Luis dan Pramudana, 2017) dengan judul "Pengaruh Green Perceived Quality, Green Satisfaction dan Green Perceived Risk Terhadap Green Trust" pada para pengguna produk ramah lingkungan pertalite di kota Denpasar, dimana pada penelitian tersebut menunjukkan bahwa green perceived risk berpengaruh negatif dan signifikan terhadap green trust. Jadi, Semakin tinggi persepsi resiko yang dirasakan oleh konsumen akan menurunkan nilai kepercayaan konsumen terhadap produk hijau yang dikonsumsi.

Penelitian yang di lakukan oleh (Dewi dan Rastini, 2016), (Luis dan Pramudana, 2017) serta (Saputro, 2013) kontradiktif dengan penelitian yang dilakukan oleh (Pratama, 2014) dengan judul "Pengaruh Green Perceived Value, Green Perceived Risk dan Green Trust Terhadap Green purchase intention Lampu Philips LED di Surabaya" menunjukkan green perceived risk berpengaruh negatif dan tidak signifikan terhadap green trust. Hal ini terjadi karena proses menciptakan kepercayaan kosumen terhadap lampu Philip LED membutuhkan waktu yang relatif lama, ini dikarenakan Lampu Philip LED terbilang baru di pasar Indonesia. Konsumen perlu memberikan bukti bahwa lampu tersebut benar-benar tidak merugikan pengguna dan lingkungan.

Dengan melihat perbedaan beberapa penelitian yang sudah dilakukan, menjadi pentingnya untuk penelitian ulang dilakukan. Sehingga memperoleh gambaran yang lebih jelas bagaimana pengaruh green perceived value dan green perceived risk terhadap green trust dan green repurchase intention, serta mengetahui pengaruh variabel yang di mediasi dari green trust. 


\section{Landasan Teori dan Pengembangan Hipotesis}

\section{Green Marketing}

Konsep green marketing mulai muncul pada akhir tahun 1980 sampai awal 1990. (Hawkins dan Mothershaugh, 2010) mendefinisikan pemasaran hijau sebagai aktivitas menjual sebuah produk dengan cara yang ramah lingkungan, termasuk memodifikasi suatu produk, merubah proses produksi, mengubah pengemasan bahkan melakukan perubahan cara promosi. Green marketing tidak hanya dapat mengubah aturan persaingan dalam praktek, tetapi juga menghasilkan strategi diferensiasi dengan memenuhi kebutuhan lingkungan pelanggan (Chen dan Chang, 2013).

\section{Green Repurchase Intention}

Kinnear dan Taylor, (1995) menyatakan minat beli sebagai komponen dari perilaku konsumen dalam sikap mengkonsumsi suatu produk, keinginan konsumen untuk bertindak sebelum mengambil keputusan untuk membeli. Minat beli ulang pada dasarnya merupakan perilaku pelanggan dalam menanggapi positif terhadap kulitas produk dan pelayanan suatu perusahaan dan berniat melakukan konsumsi kembali produk perusahaan tersebut. Sedangkan repurchase intention di kemukakan Mardalis, (2005) sebagai fungsi dari kegiatan pada periode pembelian dan merupakan sikap sebelumnya ditambah dengan kepuasan diperiode sebelumnya.Green repurchase intention merupakan perilaku dalam membeli sebuah produk yang ramah lingkungan dimana respon positif dari konsumen terhadap kualitas sebuah produk yang ramah lingkungan dan berniat untuk melakukan konsumsi kembali sebuah produk yang ramah lingkungan di perusahaan tersebut (Lam et al. 2016). Ferdinand mengadopsi dari (Dewi dan Rastini, 2016) terdapat empat dimensi minat beli ulang, yaitu minat transaksional, minat referensial, minat preferensial, minat eksploratif.

\section{Green Trust}

Kepercayaan merupakan tingkat kesediaan konsumen untuk bergantung pada suatu objek berdasarkan harapan kemampuan serta kehandalannya (Ganesan, 1994). Sedangkan kepercayaan hijau juga berarti sebuah kepercayaan yang didapat dari kemampuan dan kebaikan produk tersebut atas kepeduliannya terhadap lingkungan sehingga tumbulnya kemauan konsumen untuk bergantung pada sebuah produk, jasa ataupun merek (Ganesan, 1994). (Chen dan Chang, 2013) mengemukakan bahwa green trust memiliki 5 dimensi dalam pengukurannya sebagai berikut:

1. Terpercaya yaitu merek sudah terpercaya dalam hal komitmen menjaga lingkungan,

2. Klaim organik yaitu pernyataan konsumen akan suatu produk organik berdasarkan pengakuan ramah lingkungannya,

3. Reputasi yaitu perbuatan konsumen akan nama baik yang dimiliki dari suatu produk organik,

4. Kinerja lingkungan berkaitan dengan kepercayaan konsumen akan pencapaian suatu produk organik terhadap lingkungan,

5. Komitmen lingkungan, yaitu keyakinan konsumen akan tanggung jawab produk organik terhadap perlindungan lingkungan.

\section{Green Perceived Value}

(Zeithaml, 1988) menjelaskan persepsi nilai (perceived value) konsumen adalah keseluruhan penilaian konsumen terhadap kegunaan suatu produk atas apa yang diterima dan yang diberikan oleh produk itu. Sedangkan, green perceived value merupakan penilaian konsumen secara menyeluruh 
terhadap manfaat suatu produk dan jasa yang didasarkan pada hasrat akan kondisi lingkungan yang diinginkan konsumen, harapan berkelanjutan, dan kebutuhan hijau (Chen dan Chang, 2012). (Chen dan Chang, 2012) berpendapat bahwa green perceived value memiliki 5 dimensi dalam pengukurannya, yaitu sebagai berikut:

1. Manfaat yang didapatkan konsumen dengan menggunakan suatu produk ramah lingkungan,

2. Kinerja lingkungan yang diberikan suatu produk organik sesuai dengan harapan konsumen,

3. Kepedulian lingkungan berkaitan dengan sangat besarnya kepedulian lingkungan yang ditunjukkan dari produk organik,

4. Standar kualitas sangat baik yang ditawarkan dari produk-produk organik,

5. Baik bagi lingkungan artinya bahwa dapat mengurangi kerusakan lingkungan

\section{Green Perceived Risk}

Perceived risk dikatakan sebagai penilaian yang subjektif oleh konsumen yang berkaitan dengan konsekuensi negatif dan ketidakpastian yang dapat terjadi karena keputusan yang salah (Rahardjo, 2015). Green perceived risk didefinisikan sebagai suatu hambatan dalam mempercayakan suatu produk hijau yang dikarenakan faktor kejadian masa lalu, informasi negatif dari mulut ke mulut yang akan menyebabkan ketidakpercayaan pada suatu produk hijau (Rizwan et al., 2014). (Chen dan Chang, 2012) menyebutkan ada beberapa poin penting dalam pengukuran risiko yang dirasakan hijau adalah sebagai berikut.

1. Kemungkinan kinerja suatu produk menimbulkan sebuah permasalahan pada lingkungan.

2. Kemungkinan produk tidak bekerja sesuai rancangan yang ramah lingkungannya.

3. Kemungkinan timbulnya kerugian bagi konsumen

4. Kemungkinan produk yang digunakan dapat merusak lingkungan

5. Kemungkinan penggunaan suatu produk dapat merusak reputasi atau citra hijau konsumen.

\section{Pengembangan Hipotesis}

\section{Hubungan Green Perceived Value terhadap Green Repurchase Intention}

Perceived value yaitu seperangkat atribut yang berkaitan dengan persepsi nilai suatu produk sehingga dapat meningkatkan niat membeli kembali secara positif. (Chen dan Chang, 2012) mengemukakan green perceived value merupakan salah satu indikator yang penting untuk meneliti perilaku pembelian hijau konsumen. Hubungan nilai yang dirasakan hijau dengan niat membeli kembali hijau memliki pengaruh yang positif. Sebuah produk dapat mengantarkan nilai kepada konsumen dengan menawarkan manfaat berbeda dari produk persaing. Sebagai pembeda perusahaan memasukkan nilai lingkungan dalam suatu produk untuk menarik perhatian konsumen yang peka terhadap perubahan lingkungan saat ini. Semakin besar manfaat atau nilai produk yang diterima dan dirasakan konsumen, maka akan membentuk suatu signal minat beli ulang yang kuat dalam diri konsumen. Penelitian yang menunjukan adanya pengaruh nilai yang dirasakan hijau dengan niat membeli kembali hijau di lakukan oleh (Dewi dan Rastini, 2016) serta (Lam et al., 2016) menunjukkan bahwa green perceived value berpengaruh positif dan signifikan terhadap green repurchase intention.

$\boldsymbol{H}_{1}$ : Green perceived value berpengaruh positif dan signifikan terhadap green repurchase intention.

\section{Hubungan Green Perceived Risk terhadap Green Repurchase Intention}

Persepsi risiko merupakan manfaat negatif yang dirasakan oleh konsumen sebagai risiko yang akan didapat oleh konsumen akibat mengkonsumsi atau tidak mengkonsumsi suatu produk. Dampak dari persepsi risiko salah satunya pada perilaku pembelian hijau, 
dimana terjadi konsekuensi negatif dan ketidakpastian yang akan mempengaruhi perilaku pembelian hijau. Hasil penelitian (Dewi dan Rastini, 2016) menunjukkan bahwa green perceived risk berpengaruh negatif dan signifikan terhadap green repurchase intention. Hal ini menujukan bahwa Semakin tinggi persepsi risiko yang di dapat ketika mengkonsumsi suatu produk, mengakibatkan menurunnya minat beli ulang, sebaliknya jika persepsi resiko ini lebih sedikit dirasakan konsumen, maka minat beli ulang terhadap suatu produk akan tinggi. Dengan berkurangnya persepsi risiko dapat meningkatkan perilaku pembelian produk hijau (Waskito, 2015).

$\boldsymbol{H}_{2}$ : Green perceived risk berpengaruh negatif dan signifikan terhadap green repurchase intention.

\section{Hubungan Green Trust terhadap Green Repurchase Intention}

Kepercayaan muncul ketika satu pihak percaya kepada tindakan dari pihak lain. Kepercayaan pada suatu produk hijau akan berpengaruh terhadap perilaku pembelian hijau (Chen, 2013). Kepercayaan konsumen menjadi dasar penentu perilaku konsumen dalam waktu jangka panjang. Hasil penelitian (Dewi dan Rastini, 2016) dan (Lam et al., 2016) menunjukkan bahwa green trust berpengaruh positif dan signifikan terhadap green repurchase intention. Semakin kuat kredibilitas merek terhadap citra merek produk maka perusahaan akan mengedepankan faktor ramah lingkungan yang tertanam baik di benak konsumen akan membantu konsumen mengurangi kebingungan dalam membeli produk dan lebih memilih merek atau produk yang sudah dipercayainya. Hal ini nantinya yang akan mengarahkan pada minat beli ulang terhadap produk-produk ramah lingkungan.

$\boldsymbol{H}_{3}$ : Green trust berpengaruh positif dan signifkan terhadap green repurchase intention.

\section{Hubungan Green Perceived Value terhadap Green Trust}

Nilai yang dirasakan oleh konsumen sangat penting dalam mempengaruhi kepercayaan seorang pelanggan, karena kesadaran lingkungan yang lebih menonjol saat ini, telah banyak dieksplorasi, sehingga nilai yang dirasakan memiliki efek yang positif pada kinerja pemasaran. Jika konsumen percaya terhadap suatu produk maka konsumen akan membeli terus-menerus produk tersebut, dan apabila semakin besar nilai lingkungan suatu produk itu dipersepsikan, maka konsumen akan mengurangi perasaan skeptis konsumen dan meningkatkan kepercayaan akan produk ramah lingkungan tersebut. Penelitian yang dilakukan (Chen dan Chang, 2012), (Lam et al., 2016), dan (Dewi dan Rastini, 2016) menunjukkan bahwa green perceived value berpengaruh positif dan signifikan terhadap green trust.

$\boldsymbol{H}_{4}$ : Green perceived value berpengaruh positif dan signifikan terhadap green trust.

\section{Hubungan Green Perceived Risk terhadap Green Trust}

Pengurangan persepsi risiko mengarah pada kemungkinan meningkatnya pembelian sehingga penurunan persepsi risiko hijau yang berdampak pada peningkatan kepercayaan pelanggan. Hal ini menjadi tugas perusahaan agar dapat menurukan beberapa risiko-risiko yang dirasakan oleh konsumen untuk meningkatkan kepercayaan konsumen. Penelitian (Luis dan Pramudana, 2017) dan (Dewi dan Rastini, 2016) hasilnya menunjukkan bahwa risiko yang dirasakan hijau berpengaruh negatif dan signifikan terhadap kepercayaan hijau. Semakin besar persepsi konsumen bahwa produk ramah lingkungan itu tidak benar-benar aman dan hanya sebagai strategi untuk meningkatkan penjualan membawa keraguan dan kekhawatiran pada diri konsumen yang akhirnya berakibat menurunnya kepercayaan terhadap risiko suatu produk. Kedua penelitian diatas kontradiktif dengan penelitian yang 
dilakukan oleh (Pratama, 2014) dimana green perceived risk berpengaruh negatif dan tidak signifikan terhadap green trust.

$H_{5}$ : Green perceived risk berpengaruh negatif dan signifikan terhadap green trust.

\section{Hubungan Green Perceived Value terhadap Green Repurchase Intention yang dimediasi oleh Green Trust}

Nilai yang dirasakan konsumen dapat mempengaruhi kepercayaan suatu konsumen, persepsi nilai tinggi yang dirasakan konsumen dapat meningkatkan kepercayaan konsumen (Kim et al., 2008). Kepercayaan akan suatu produk hijau ini akan mempengaruhi perilaku pembelian hijau (Chen, 2013). Hasil penelitian (Dewi dan Rastini, 2016) serta (Lam et al., 2016) menunjukkan bahwa green trust secara signifikan mampu memediasi pengaruh green perceived value terhadap green repurchase intention. Hal tersebut dikarenakan semakin tinggi kredibilitas kemampuan suatu produk hijau, maka persepsi konsumen akan kepercayaan produk hijau tersebut meningkat sehingga mengarahkan pada minat beli ulang akan produk ramah lingkungan tersebut.

$\boldsymbol{H}_{6}$ : Green trust mampu memediasi green perceived value terhadap green repurchase intention.

\section{Hubungan Green Perceived Risk terhadap Green Repurchase Intentionyang dimediasi oleh Green Trust}

Green perceived risk dinyatakan sebagai harapan negatif yang berkonsekuensi pada lingkungan terkait dengan perilaku pembelian (Chen dan Chang, 2012). Setiap konsumen yang melakukan pembelian pasti di dasarkan pada rasa percaya dari brand product, dimana banyak penelitian yang menyatakan bahwa kepercayaan dapat mengatasi persepsi risiko yang dimiliki oleh setiap konsumen. Penelitian yang dilakukan oleh (Dewi dan Rastini, 2016) menunjukkan bahwa green trust secara signifikan mampu memediasi pengaruh green perceived risk terhadap green repurchase intention dengan parameter negatif. Hal tersebut terjadi karena semakin rendah resiko produk yang di persepsikan konsumen, maka semakin tinggi nilai kepercayaan bahwa produk tersebut memiliki kinerja yang baik terhadap lingkungan yang akhirnya meningkatkan minat beli ulang terhadap produk.

H7: Green trust mampu memediasi green perceived risk terhadap green repurchase intention.

Berdasarkan perumusan hipotesis tersebut, maka model penelitian dalam penelitian ini adalah sebagai berikut:

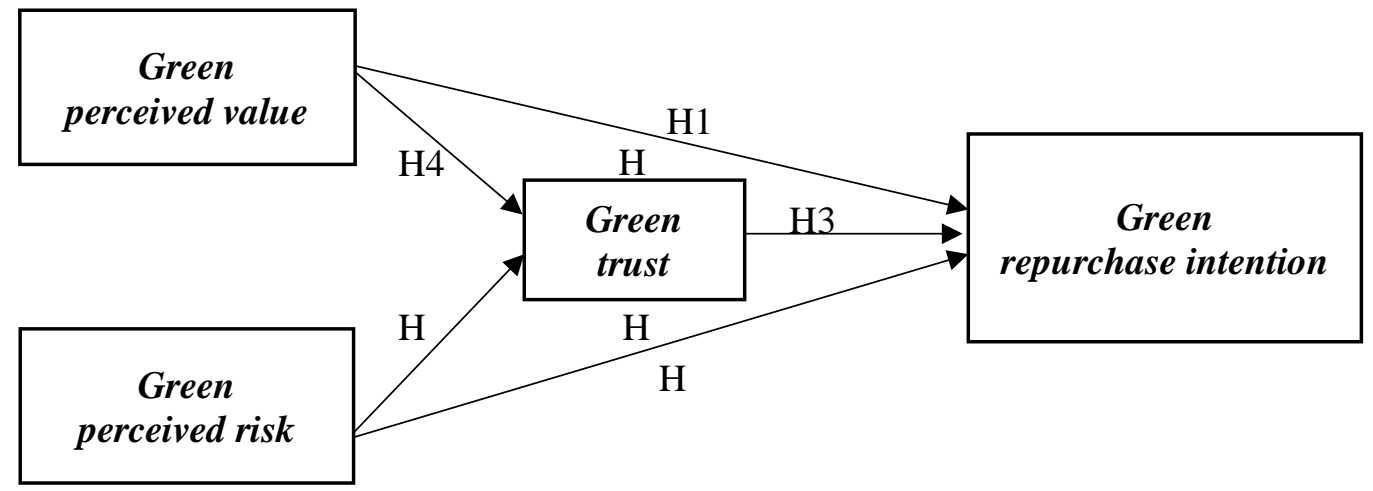

Gambar 1. Model Penelitian

(Sumber : Diadopsi dari penelitian Chen dan Chang, (2012), Pratama, (2014), dan Dewi dan Rastini, (2016)). 


\section{Metode Penelitian}

\section{Definisi operasional variabel}

Tabel 2. Definisi Operasional Variabel Penilitian

\begin{tabular}{|c|c|c|c|}
\hline NO & Variabel & Definisi Operasional Variabel & Indikator \\
\hline \multicolumn{4}{|c|}{ Variabel Dependent } \\
\hline 1 & $\begin{array}{l}\text { Green } \\
\text { repurchase } \\
\text { intention }(\mathrm{Y})\end{array}$ & $\begin{array}{l}\text { Green repurchase intention merupakan } \\
\text { perilaku dalam membeli sebuah produk } \\
\text { yang ramah lingkungan dimana respon } \\
\text { positif dari konsumen terhadap kualitas } \\
\text { sebuah produk yang ramah lingkungan dan } \\
\text { berniat untuk melakukan konsumsi kembali } \\
\text { sebuah produk yang ramah lingkungan di } \\
\text { perusahaan tersebut Lam } \text { et al., (2016). }\end{array}$ & $\begin{array}{l}\text { 1. minat transaksional, } \\
\text { 2. minat referensial, } \\
\text { 3. minat minat preferensial, } \\
\text { dan } \\
\text { 4. minat eskploratif. Dewi } \\
\text { dan Rastini, (2016) }\end{array}$ \\
\hline \multicolumn{4}{|c|}{ Variabel Independent } \\
\hline 1 & $\begin{array}{l}\text { Green perceived } \\
\text { value (X1) }\end{array}$ & $\begin{array}{l}\text { green perceived value merupakan penilaian } \\
\text { konsumen secara menyeluruh terhadap } \\
\text { manfaat suatu produk dan jasa yang } \\
\text { didasarkan pada hasrat akan kondisi } \\
\text { lingkungan yang diinginkan konsumen, } \\
\text { harapan berkelanjutan, dan kebutuhan hijau } \\
\text { Chen dan Chang, (2012). }\end{array}$ & $\begin{array}{l}\text { 1. Manfaat lingkungan } \\
\text { 2. Kinerja lingkungan } \\
\text { sesuai harapan } \\
\text { 3. Kepedulian lingkungan } \\
\text { 4. Ramah lingkungan } \\
\text { 5. Baik bagi lingkungan } \\
\text { Chen dan Chang, (2012). }\end{array}$ \\
\hline 2 & $\begin{array}{l}\text { Green perceived } \\
\text { risk }(\mathrm{X} 2)\end{array}$ & $\begin{array}{l}\text { Green perceived risk didefinisikan sebagai } \\
\text { suatu hambatan dalam mempercayakan } \\
\text { suatu produk hijau yang dikarenakan faktor } \\
\text { kejadian masa lalu, informasi negatif dari } \\
\text { mulut ke mulut yang akan menyebabkan } \\
\text { ketidakpercayaan pada suatu produk hijau } \\
\text { Rizwan } \text { et al., (2014) }\end{array}$ & $\begin{array}{l}\text { 1. kinerja lingkungan } \\
\text { bermasalah } \\
\text { 2. kinerja lingkungan tidak } \\
\text { sesuai design kemasan } \\
\text { 3.hukuman/kerugian } \\
\text { lingkungan } \\
\text { 4. Merusak lingkungan } \\
\text { 5. Merusak citra hijau } \\
\text { konsumen Chen dan } \\
\text { Chang, (2012). }\end{array}$ \\
\hline \multicolumn{4}{|c|}{ Variabel Mediasi } \\
\hline 1 & Green trust $(\mathrm{M})$ & $\begin{array}{l}\text { Green trust juga berarti sebuah kepercayaan } \\
\text { yang didapat dari kemampuan dan kebaikan } \\
\text { produk tersebut atas kepeduliannya terhadap } \\
\text { lingkungan sehingga tumbulnya kemauan } \\
\text { konsumen untuk bergantung pada sebuah } \\
\text { produk, jasa ataupun merek Ganesan, } \\
\text { (1994). }\end{array}$ & $\begin{array}{l}\text { 1. Reputasi lingkungan } \\
\text { 2. kinerja lingkungan } 3 . \\
\text { klaim ramah lingkungan } \\
\text { 4. kepedulian lingkungan } \\
\text { sesuai harapan } \\
\text { 5. komitmen terhadap } \\
\text { lingkungan Chen dan } \\
\text { Chang, (2013). }\end{array}$ \\
\hline
\end{tabular}

Jenis penelitian ini bersifat kuantitatif. Penelitian kuantitatif merupakan sebuah proses yang memungkinkan peneliti untuk membangun hipotesis dan menguji secara empiris hipotesis yang dibangun. Populasi dalam penelitian ini adalah seluruh konsumen pengguna BBM jenis pertalite pada masyarakat Kota Ternate. Sampel penelitian ini didapat dengan kriteria yaitu konsumen yang memakai produk BBM jenis pertalite lebih dari 2 kali sebagai acuan untuk mendapatkan responden yang benar-benar memiliki niat beli kembali produk. Dengan teknik pengambilan sampel yaitu Purposive Sampling. Teknik Purposive Sampling 
adalah teknik penentuan sampel dengan pertimbangan tertentu (Sugiyono, 2015). Pembagian angket kuesioner di lakukan dengan secara langsung di lapangan. Untuk pertimbangan sampel dalam penelitian ini yaitu semua yang memakai produk BBM jenis pertalite lebih dari 2 kali, sedangkan konsumen yang suka berganti merek produk BBM (premium atau pertamax) tidak termasuk dalam sampel penelitian. Penentuan sampel didasarkan pada Hair, et al (1998) yang menyatakan bahwa jumlah sampel dalam penelitian adalah sebagai berikut:

$\mathrm{N}=$ Jumlah Indikator $\mathrm{x} 5$

$\mathrm{N}=19 \times 5$

$\mathrm{N}=95$ responden

Sumber data yang digunakan dalam penelitian ini terdiri dari data primer dan data sekunder. Data primer merupakan data yang diperoleh secara langsung dilokasi penelitian menggunakan kuesioner, yang merupakan sejumlah pertanyaan tertulis yang digunakan untuk memperoleh sebuah informasi dari responden dalam arti laporan tentang pribadi konsumen atau hal-hal yang diketahui (Arikunto, 2006). Sedangkan Teknik pengumpulan data sekunder menggunakan metode dokumentasi yaitu suatu metode yang digunakan untuk memperoleh atau mengetahui sesuatu dengan melihat buku, artikel atau catatan-catatan, literatur dan jurnal yang berhubungan dengan masalah yang dibahas dan mendukung pelaksanaan penelitian. Instrumen dalam penelitian ini dilakukan dengan bantuan program software IBM SPSS statistics 26 for windows. Sebelum menguji hipotesis terlebih dahulu menguji instrument. Pengujian ini dilakukan untuk mengetahui apakah instrument yang digunakan sudah valid dan reliabel kemudian menguji asumsi klasik. Hal ini agar hasil perhitungan tersebut dapat diinterpretasikan dengan tepat dan efisien. Setelah itu peneliti melakukan Uji hipotesis, uji ini digunakan untuk menguji hipotesis dalam penelitian. Uji hipotesis yang digunakan dalam penelitian ini adalah uji t (uji persial) dan uji pengaruh mediasi (path analysis dan uji sobel). uji Analisis Jalur (Path Analysis) ini merupakan perluasan dari analisis regresi berganda, analisis jalur dalam analisis regresi digunakan untuk menaksir hubungan kausalitas antar variabel yang telah ditetapkan sebelumnya berdasarkan teori. Koefisien jalur adalah standardized koefisien regresi (Ghozali, 2013). Uji sobel dilakukan dengan cara menguji kekuatan pengaruh tidak langsung variabel independen (X) ke variabel dependen (Y) melalui variabel intervening (M).

\section{Hasil Pembahasan}

\section{Hasil Analisis Deskriptif Penelitian}

Berdasarkan tabel 3 berikut ini menunjukkan bahwa interpretasi jawaban responden untuk semua variabel penelitian adalah berada pada kategori Baik.

Tabel 3. Hasil Analisis Deskriptif Penelitian

\begin{tabular}{|c|c|c|c|c|c|c|c|}
\hline No & Variabel & N & Min & Max & Mean & Std Deviasi & Keterangan \\
\hline 1 & $\begin{array}{c}\text { Green } \\
\text { perceived } \\
\text { value }\end{array}$ & 95 & 1.40 & 5.00 & 4,14 & 0.694 & Baik \\
\hline 2 & $\begin{array}{c}\text { Green } \\
\text { perceived risk }\end{array}$ & 95 & 3.00 & 5.00 & 3,64 & 0.662 & Baik \\
\hline 3 & $\begin{array}{c}\text { Green trust } \\
\text { Green } \\
\text { repurchase } \\
\text { intention }\end{array}$ & 95 & 2.20 & 5.00 & 4,15 & 0.634 & Baik \\
\hline
\end{tabular}

Sumber: Data primer diolah, 2021 


\section{Hasil Uji Instrumen Data}

Pengujian instrument digunakan untuk menguji validitas dan reliabilitas instrument yang disusun apakah layak digunakan sebagai alat ukur penelitian. Uji validitas dapat dilihat pada Output Cronbach Alpha kolom corrected Item Total Correlation. Dasar pengambilan keputusan dengan membandingkan dengan nilai $\mathrm{r}$ tabel, yang dicari pada signifikasi 0,05 dengan uji 2 sisi dan jumlah data awal $(n)=95$, df $=n-2$, maka didapat $r$ tabel sebesar 0,202. Hasil uji validitas dari 19 instrumen dapat disimpulkan bahwa semua butir-butir pertanyaan atau indikator penelitian dinyatakan valid. sedangkan Perhitungan reliabilitas dapat dilihat pada output hasil pengolahan SPSS pada alpha cronbach's, bila mana suatu kuesioner dianggap reliabel apabila Cronbach's alpha $>0,600$. hasil uji reliabilitas pada tabel dibawah, semua variabel memperoleh koefisien cronbach's alpha lebih besar dari 0,60 Hal ini menunjukkan bahwa seluruh item kuesioner dinyatakan reliabel, dan semua item kuesioner layak untuk di uji.

Tabel 4. Hasil Uji Validitas dan Reabilitas

\begin{tabular}{|c|c|c|c|c|c|c|c|}
\hline Variabel & $\begin{array}{l}\text { indikat } \\
\text { or }\end{array}$ & $\begin{array}{l}\text { Corrected } \\
\text { Item- Total } \\
\text { (rhitung) }\end{array}$ & rtabel & Validitas & $\begin{array}{c}\text { Cronbach's } \\
\text { Alpha }\end{array}$ & $\begin{array}{c}\text { Critical } \\
\text { Value }\end{array}$ & Keterangan \\
\hline \multirow{5}{*}{$\begin{array}{c}\text { Green } \\
\text { Perceived } \\
\text { Value (XI) }\end{array}$} & 1 & 0,802 & 0,202 & Valid & \multirow{5}{*}{0,785} & \multirow{5}{*}{0,60} & \multirow{5}{*}{ Reliabel } \\
\hline & 2 & 0,637 & 0,202 & Valid & & & \\
\hline & 3 & 0,787 & 0,202 & Valid & & & \\
\hline & 4 & 0,795 & 0,202 & Valid & & & \\
\hline & 5 & 0,671 & 0,202 & Valid & & & \\
\hline \multirow{5}{*}{$\begin{array}{c}\text { Green } \\
\text { Perceived } \\
\text { Risk }(X 2)\end{array}$} & 1 & 0,636 & 0,202 & Valid & \multirow{5}{*}{0,625} & \multirow{5}{*}{0,60} & \multirow{5}{*}{ Reliabel } \\
\hline & 2 & 0,533 & 0,202 & Valid & & & \\
\hline & 3 & 0,728 & 0,202 & Valid & & & \\
\hline & 4 & 0,604 & 0,202 & Valid & & & \\
\hline & 5 & 0,662 & 0,202 & Valid & & & \\
\hline \multirow{5}{*}{$\begin{array}{l}\text { Green Trust } \\
\text { (M) }\end{array}$} & 1 & 0,716 & 0,202 & Valid & \multirow{5}{*}{0,824} & \multirow{5}{*}{0,60} & \multirow{5}{*}{ Reliabel } \\
\hline & 2 & 0,767 & 0,202 & Valid & & & \\
\hline & 3 & 0,778 & 0,202 & Valid & & & \\
\hline & 4 & 0,760 & 0,202 & Valid & & & \\
\hline & 5 & 0,815 & 0,202 & Valid & & & \\
\hline \multirow{4}{*}{$\begin{array}{c}\text { Green } \\
\text { Repurchase } \\
\text { Intention }(Y)\end{array}$} & 1 & 0,801 & 0,202 & Valid & \multirow{4}{*}{0,774} & \multirow{4}{*}{0,60} & \multirow{4}{*}{ Reliabel } \\
\hline & 2 & 0,784 & 0,202 & Valid & & & \\
\hline & 3 & 0,862 & 0,202 & Valid & & & \\
\hline & 4 & 0,679 & 0,202 & Valid & & & \\
\hline
\end{tabular}

Sumber: Data primer diolah, 2021

\section{Uji Normalitas}

Tabel 5. Hasil Uji Normalitas

\begin{tabular}{|c|c|c|}
\hline Persamaan & Nilai p-value (sig.) & Keterangan \\
\hline I & 0,191 & Data terdistribusi Normal \\
\hline II & 0,184 & Data terdistribusi Normal \\
\hline
\end{tabular}

Sumber: Data primer diolah, 2021

Pada hasil uji statistik Kolmogrov-Smirnov tabel 5 diatas menunjukkan bahwa, persamaan I memiliki p-value 0,191 >0,05. Persamaan II juga menunjukkan hal yang sama, p-value $0,184>0,05$, sehingga dapat disimpulkan bahwa pada kedua persamaan, nilai residual keduannya terdistribusi normal dan telah memenuhi asumsi normalitas. 


\section{Uji Koefisien Determinasi $\left(\mathbf{R}^{2}\right)$}

Uji koefisien determinasi digunakan untuk mengukur sejauh mana kemampuan model regresi menerangkan variabel dependen.

Tabel 6. Hasil Uji Koefisien Determinasi Persamaan I

\begin{tabular}{|l|c|l|l|l|l|}
\hline \multicolumn{7}{|c|}{ Model Summary $^{\mathbf{b}}$} \\
\hline Model & $\mathrm{R}$ & R Square & $\begin{array}{l}\text { Adjusted R } \\
\text { Square }\end{array}$ & $\begin{array}{l}\text { Std. Error of } \\
\text { the Estimate }\end{array}$ & Durbin-Watson \\
\hline 1 & $.680^{\mathrm{a}}$ & .462 & .450 & 1.802 & 2.236 \\
\hline a. Predictors: (Constant), Green Perceived Risk, Green Perceived Value \\
\hline \multicolumn{2}{|l}{ b. Dependent Variable: Green Trust } \\
\hline
\end{tabular}

Sumber: Data primer diolah, 2021

Hasil uji koefisien determinasi pada persamaan I tabel 6, diperoleh nilai adjusted $\mathrm{R}$ square sebesar 0,462 yang berarti bahwa proporsi pengaruh variabel green perceived value dan green perceived risk terhadap green trust hanya sebesar $46,2 \%$, sedangkan sisanya $53,8 \%$ dipengaruhi oleh faktor-faktor lain yang tidak diteliti dalam penelitian ini.

Tabel 7. Hasil Uji Koefisien Determinasi Persamaan II

\begin{tabular}{|l|c|c|l|l|l|}
\hline \multicolumn{7}{|c|}{ Model Summary $^{\mathbf{b}}$} \\
\hline \multicolumn{1}{|c|}{ Model } & $\mathrm{R}$ & $\mathrm{R}$ Square & $\begin{array}{l}\text { Adjusted R } \\
\text { Square }\end{array}$ & $\begin{array}{l}\text { Std. Error of } \\
\text { the Estimate }\end{array}$ & Durbin-Watson \\
\hline 1 & $.711^{\mathrm{a}}$ & .506 & .490 & 1.524 & 2.053 \\
\hline a. Predictors: (Constant), Green Trust, Green Perceived Risk, Green Perceived Value \\
\hline
\end{tabular}

Sumber: Data primer diolah, 2021

Berdasarkan hasil uji koefisien determinasi pada tabel 7, diperoleh nilai adjusted $\mathrm{R}$ square sebesar 0,506 yang berarti bahwa proporsi pengaruh variabel green perceived value, green perceived risk, dan green trust terhadap green repurchase intention hanya sebesar $50,6 \%$, sedangkan sisanya $49,4 \%$ dipengaruhi oleh faktor-faktor lain yang tidak diteliti dalam penelitian ini.

\section{Uji F}

Uji F digunakan untuk menguji apakah semua variabel independen yang dimasukkan dalam model mempunyai pengaruh secara bersama-sama atau simultan terhadap variabel dependen.

Tabel 8. Hasil Uji F Persamaan I

\begin{tabular}{|l|l|r|r|r|r|c|}
\hline \multicolumn{7}{|l|}{ ANOVA $^{\mathrm{a}}$} \\
\hline \multirow{2}{*}{ Model } & $\begin{array}{c}\text { Sum of } \\
\text { Squares }\end{array}$ & \multicolumn{1}{c|}{ Df } & $\begin{array}{c}\text { Mean } \\
\text { Square }\end{array}$ & \multicolumn{1}{c|}{ F } & Sig. \\
\hline 1 & Regression & 256.228 & 2 & 128.114 & 39.465 & $.000^{\mathrm{b}}$ \\
\cline { 2 - 7 } & Residual & 298.656 & 92 & 3.246 & & \\
\cline { 2 - 7 } & Total & 554.884 & 94 & & & \\
\hline \multicolumn{6}{|l}{ a. Dependent Variable: Green Trust } \\
\hline
\end{tabular}

Sumber: Data primer diolah, 2021 
Berdasarkan data pada tabel 8 di atas, diketahui $f_{\text {hitung }}$ sebesar 39,465 dengan $\mathrm{f}_{\text {tabel }}$ 3,09 , yang berarti $\mathrm{f}_{\text {hitung }}$ lebih besar dari $\mathrm{f}_{\text {tabel. }}$. Atau dengan membandingkan $p$-value (sig.) 0,000 dengan tigkat signifikasi 0,05 yang berarti lebih kecil. Jadi model regresi I yang digunakan sudah tepat, yaitu variabel green perceived value dan green perceived risk secara simultan berpengaruh terhadap green trust.

Tabel 9. Hasil Uji F Persamaan II

\begin{tabular}{|c|c|c|c|c|c|c|}
\hline \multicolumn{7}{|c|}{ ANOVAa $^{\mathrm{a}}$} \\
\hline \multicolumn{2}{|c|}{ Model } & $\begin{array}{c}\text { Sum of } \\
\text { Squares }\end{array}$ & Df & Mean Square & $\mathrm{F}$ & Sig. \\
\hline \multirow[t]{3}{*}{1} & Regression & 216.462 & 3 & 72.154 & 31.064 & $.000^{\mathrm{b}}$ \\
\hline & Residual & 211.369 & 91 & 2.323 & & \\
\hline & Total & 427.832 & 94 & & & \\
\hline \multicolumn{7}{|c|}{ a. Dependent Variable: Green Repurchase Intention } \\
\hline \multicolumn{7}{|c|}{ b. Predictors: (Constant), Green Trust, Green Perceived Risk, Green Perceived Value } \\
\hline
\end{tabular}

Sumber: Data primer diolah, 2021

Berdasarkan data pada tabel 9 diatas, diketahui $\mathrm{f}_{\text {hitung }}$ sebesar 31,064 dan $\mathrm{f}_{\text {tabel }} 2,70$, yang berarti $f_{\text {hitung }}$ lebih besar $f_{\text {tabel. }}$. Atau dengan membandingkan p-value (sig.) 0,000 dengan tigkat signifikan 0,05 yang berarti lebih kecil. Jadi model regresi II yang digunakan sudah tepat, yaitu variabel green perceived value, green perceived risk dan green trust secara simultan berpengaruh terhadap green repurchase intention.

\section{Uji Persial (Uji t)}

Uji t digunakan untuk menunjukkan seberapa jauh pengaruh satu variabel bebas secara individu dalam menerangkan variasi variabel dependen. Hasil uji t dalam penelitian ini sebagai berikut. Pengambilan keputusan untuk uji t untuk persamaan kedua juga didasarkan perbandingkan nilai signifikasi yang telah ditetapkan, yaitu dengan tingkat signifikasi 0,05 dan df (92), maka diperoleh nilai ttabel 1,986.

Tabel 10. Hasil Uji t Persamaan I

\begin{tabular}{|c|c|c|c|c|c|c|}
\hline \multicolumn{7}{|c|}{ Coefficients $^{\mathbf{a}}$} \\
\hline & & \multicolumn{2}{|c|}{$\begin{array}{l}\text { Unstandardized } \\
\text { Coefficients }\end{array}$} & \multirow{2}{*}{$\begin{array}{c}\text { Standardized } \\
\text { Coefficients } \\
\text { Beta } \\
\end{array}$} & \multirow[b]{2}{*}{$\mathrm{t}$} & \multirow[b]{2}{*}{ Sig. } \\
\hline \multicolumn{2}{|c|}{ Model } & $\mathrm{B}$ & Std. Error & & & \\
\hline \multirow[t]{3}{*}{1} & $($ Constant $)$ & 5.252 & 2.103 & & 2.497 & .014 \\
\hline & Green Perceived Value & .623 & .073 & .655 & 8.507 & .000 \\
\hline & Green Perceived Risk & .142 & .089 & .122 & 1.587 & .116 \\
\hline
\end{tabular}

Sumber: Data primer diolah, 2021

Berdasarkan tabel 10 diatas, maka dapat dilakukan pengujian hipotesis untuk untuk setiap variabel independen sebagai berikut:

a. Pengaruh variabel green perceived value (X1)

Berdasarkan hasil analisis uji $\mathrm{t}$ diperoleh $\mathrm{t}_{\text {hitung }}$ untuk variabel $\mathrm{X} 1$ sebesar 8,507 dengan $\mathrm{t}_{\text {tabel }}=1,986$ maka nilai $\mathrm{t}_{\text {hitung }}$ lebih besar dari $\mathrm{t}_{\text {tabel }}$. Sedangkan nilai $p$-value (sig.) $0,000<\alpha(0,05)$. Berdasarkan hasil tersebut maka H0 ditolak dan Ha diterima yang berarti secara parsial green perceived value (X1) berpengaruh positif dan signifikan terhadap green trust (M). 
b. Pengaruh green perceived risk (X2).

Berdasarkan hasil analisis uji t diperoleh thitung untuk variabel X1 sebesar 1,587 dengan $\mathrm{t}_{\text {tabel }}=1,986$ maka nilai $\mathrm{t}_{\text {hitung }}$ lebih kecil dari $\mathrm{t}_{\text {tabel. }}$. Sedangkan nilai $p$-value (sig.) $0,116>\alpha(0,05)$. Berdasarkan hasil tersebut maka H0 diterima dan Ha ditolak yang berarti secara parsial green perceived risk (X2) berpengaruh positif dan tidak signifikan teradap green trust $(\mathrm{M})$.

Pengambilan keputusan untuk uji $\mathrm{t}$ untuk persamaan kedua juga didasarkan perbandingkan nilai signifikasi yang telah ditetapkan, yaitu dengan tingkat signifikasi 0,05 dan df (91), maka diperoleh nilai $t_{\text {tabel }}$ 1,986.

Tabel 11. Hasil Uji t Persamaan II

\begin{tabular}{|c|c|c|c|c|c|c|}
\hline \multicolumn{7}{|c|}{ Coefficients $^{\mathrm{a}}$} \\
\hline & & \multicolumn{2}{|c|}{$\begin{array}{l}\text { Unstandardized } \\
\text { Coefficients }\end{array}$} & \multirow{2}{*}{$\begin{array}{l}\text { Standardized } \\
\text { Coefficients } \\
\text { Beta }\end{array}$} & \multirow[b]{2}{*}{$\mathrm{T}$} & \multirow[b]{2}{*}{ Sig. } \\
\hline \multicolumn{2}{|c|}{ Model } & B & Std. Error & & & \\
\hline \multirow[t]{4}{*}{1} & $($ Constant $)$ & 3.600 & 1.838 & & 1.959 & .053 \\
\hline & Green Perceived Value & .372 & .083 & .445 & 4.495 & .000 \\
\hline & Green Perceived Risk & -.045 & .077 & -.044 & -.583 & .561 \\
\hline & Green Trust & .297 & .088 & .338 & 3.367 & .001 \\
\hline
\end{tabular}

Sumber: Data primer diolah, 2019

Berdasarkan tabel 11 di atas maka dapat dilakukan pengujian hipotesis untuk untuk setiap variabel independen sebagai berikut:

a. Pengaruh green perceived value (X1)

Berdasarkan hasil analisis uji $\mathrm{t}$ diperoleh $\mathrm{t}_{\text {hitung }}$ untuk variabel X1 sebesar 4,495 dengan $\mathrm{t}_{\text {tabel }}=1,986$ maka nilai $\mathrm{t}_{\text {hitung }}$ lebih besar dari $\mathrm{t}_{\text {tabel. }}$. Sedangkan nilai $p$-value (sig.) $0,000<\alpha(0,05)$. Berdasarkan hasil tersebut maka $\mathrm{H} 0$ ditolak dan Ha diterima yang berarti secara parsial green perceived value (X1) berpengaruh positif dan signifikan terhadap green repurchase intention $(\mathrm{Y})$.

b. Pengaruh green perceived risk (X2)

Berdasarkan hasil analisis uji t diperoleh thitung untuk variabel X2 sebesar -0,583 maka nilai $t_{\text {hitung }}<\mathrm{t}_{\text {tabel }} 1,986$. Sedangkan nilai $p$-value (sig.) $0,561>\alpha(0,05)$. Berdasarkan hasil tersebut maka H0 diterima dan Ha ditolak yang berarti secara parsial green perceived risk (X2) berpengaruh negatif dan tidak signifikan terhadap green repurchase intention (Y).

c. Pengaruh green trust $(\mathrm{M})$

Berdasarkan hasil analisis uji t diperoleh thitung untuk variabel $\mathrm{M}$ sebesar 3,367 maka nilai $t_{\text {hitung }}$ lebih besar dari $t_{\text {tabel }} 1,986$. Sedangkan $p$-value (sig.) $0,001<\alpha(0,05)$. Berdasarkan hasil tersebut maka $\mathrm{H} 0$ ditolak dan Ha diterima yang berarti secara parsial green trust (M) berpengaruh positif dan signifikan terhadap green repurchase intention (Y).

\section{Hasil Uji Analisis Jalur (Path Analysis)}

Pengujian data penelitian ini menggunakan teknik analisis jalur (Path Analysis), dimana analisis jalur adalah perluasan dari analisis regresi linear berganda untuk menguji hubungan kausalitas antara dua atau lebih variabel. Hasil analisis untuk mengetahui persamaan struktural I, dan persamaan struktural I analisis jalur adalah sebagai berikut: 
Tabel 12. Hasil Uji analisis jalur (Path Analysis) Persamaan I

\begin{tabular}{|l|c|c|c|c|c|}
\hline \multirow{2}{*}{ Model } & \multicolumn{2}{|c|}{$\begin{array}{c}\text { Unstandarized } \\
\text { coeficients }\end{array}$} & $\begin{array}{c}\text { Standarized } \\
\text { coeficients }\end{array}$ & $\mathrm{T}$ & \multirow{2}{*}{ Sig. } \\
\cline { 2 - 6 } & $\mathrm{B}$ & Std.Eror & Beta & & \\
\hline 1. (Consonant) & 5,252 & 2,103 & & 2,497 & 0,014 \\
\hline Green percv. Value & 0,623 & 0,073 & 0,655 & 8,507 & 0,000 \\
\hline Green percv. Risk & 0,142 & 0,089 & 0,122 & 1,587 & 0,116 \\
\hline $\mathrm{R}^{2}$ & 0,462 & & & & \\
\hline Fhitung & 39,465 & & & & \\
\hline Sig. F & 0,000 & & & & \\
\hline
\end{tabular}

Sumber: Data primer diolah, 2021

Berdasarkan hasil analisis sub struktural I yang disajikan pada tabel, maka persamaan strukturalnya adalah sebagai berikut:

$\mathrm{M}=\beta 1 \mathrm{X} 1+\beta 2 \mathrm{X} 2+\beta 3 \mathrm{X} 3+\mathrm{e} 1$

$\mathrm{M}=0,655 \mathrm{X} 1+0,122 \mathrm{X} 2+\mathrm{e} 1$

Tabel 13. Hasil Uji analisis jalur (Path Analysis) Persamaan II

\begin{tabular}{|l|c|c|c|c|c|}
\hline \multirow{2}{*}{ Model } & \multicolumn{2}{|c|}{ Unstandarized coeficients } & $\begin{array}{c}\text { Standarized } \\
\text { coeficients }\end{array}$ & \multirow{2}{*}{$\mathrm{T}$} & \multirow{2}{*}{ Sig. } \\
\cline { 2 - 5 } & $\mathrm{B}$ & Std.Eror & Beta & & \\
\hline 1. (Consonant) & 3,600 & 1,838 & & 1,959 & 0,053 \\
\hline Green percv. Value & 0,372 & 0,083 & 0,445 & 4,495 & 0,000 \\
\hline Green percv. Risk & $-0,045$ & 0,077 & $-0,044$ & $-0,583$ & 0,561 \\
\hline Green trust & 0,297 & 0,088 & 0,338 & 3,367 & 0,001 \\
\hline $\mathrm{R}^{2}$ & 0,506 & & & & \\
\hline Fhitung & 31,064 & & & & \\
\hline Sig. F & 0,000 & & & & \\
\hline
\end{tabular}

Sumber: Data primer diolah, 2021

Berdasarkan hasil analisis sub struktural II, maka persamaan strukturalnya adalah sebagai berikut:

$\mathrm{Y}=\beta 1 \mathrm{X} 1+\beta 2 \mathrm{X} 2+\beta 3 \mathrm{M}+\mathrm{e} 2$

$\mathrm{Y}=0,445 \mathrm{X} 1-0,044 \mathrm{X} 2+0,338 \mathrm{M}+\mathrm{e} 2$

Nilai standar eror dapat dihitung sebagai berikut.

$\mathrm{e} 1=\sqrt{1-R 2}$, maka e $1=\sqrt{1-0,462}=0,733$

$\mathrm{e} 2=\sqrt{1-R 2,}$ maka e $1=\sqrt{1-0,506}=0,703$

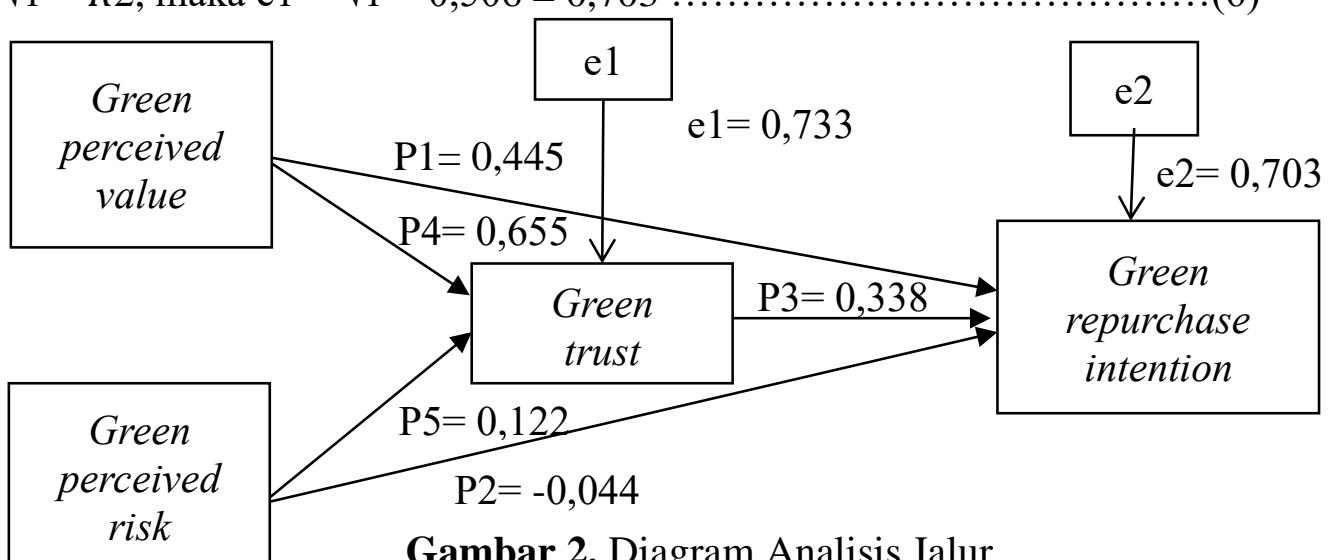

Gambar 2. Diagram Analisis Jalur

(Sumber: Data primer diolah, 2021) 
a. Persamaan I Hubungan mediasi green perceived value terhadap green repuurchase intention melalui green trust.

Tabel 14. pengaruh langsung, pengaruh tidak langsung, serta pengaruh total green perceived value, green trust, green repurchase intention.

\begin{tabular}{|c|c|c|c|}
\hline Pengaruh variabel & $\begin{array}{c}\text { Pengaruh } \\
\text { langsung }\end{array}$ & $\begin{array}{c}\text { Pengaruh tidak } \\
\text { langsung }\end{array}$ & Pengaruh total \\
\hline $\mathrm{X} 1 \rightarrow \mathrm{Y}$ & 0,445 & & 0,445 \\
\hline $\mathrm{X} 1 \rightarrow \mathrm{M}$ & 0,655 & & 0,655 \\
\hline $\mathrm{M} \rightarrow \mathrm{Y}$ & 0,338 & & 0,338 \\
\hline $\mathrm{X} 1 \rightarrow \mathrm{M} \rightarrow \mathrm{Y}$ & & $\begin{array}{c}(0,655 \times 0,338)= \\
0,221\end{array}$ & $(0,445+0,221)=0,666$ \\
\hline
\end{tabular}

Sumber: Data primer diolah, 2021

Hasil analisis jalur menunjukkan bahwa green perceived value memiliki pengaruh langsung ke green repurchase intention (P1) sebesar 0,445 sedangkan besarnya pengaruh tidak langsung (melalui green trust) dapat dihitung dengan mengalihkan koefisien tidak langsungnya yaitu $\mathrm{P} 2(0,655) \times \mathrm{P} 3(0,338)=0,221$. Adapun total pengaruh green perceived value ke green repurchase intention $=(0,445)+(0,221)=0,666$.

b. Persamaan II Hubungan mediasi green perceived risk terhadap green repurchase intention melalui green trust.

Tabel 15. pengaruh langsung, pengaruh tidak langsung serta pengaruh total green perceived risk, green trust, green repurchase intention

\begin{tabular}{|c|c|c|c|}
\hline Pengaruh variabel & Pengaruh langsung & $\begin{array}{c}\text { Pengaruh tidak } \\
\text { langsung }\end{array}$ & Pengaruh total \\
\hline $\mathrm{X} 2 \rightarrow \mathrm{Y}$ & $-0,044$ & & \\
\hline $\mathrm{X} 2 \rightarrow \mathrm{M}$ & 0,122 & & 0,122 \\
\hline $\mathrm{M} \rightarrow \mathrm{Y}$ & 0,338 & & 0,338 \\
\hline $\mathrm{X} 2 \rightarrow \mathrm{M} \rightarrow \mathrm{Y}$ & & $(0,122 \times 0,338)=$ & $(-0,044+0,041)=-$ \\
& & 0,041 & 0,003 \\
\hline
\end{tabular}

Sumber: Data primer diolah, 2021

Hasil analisis jalur menunjukkan bahwa green perceived risk memiliki pengaruh langsung ke green repurchase intention hanya sebesar - 0,044 sedangkan besarnya pengaruh tidak langsung (melalui green trust) dapat dihitung dengan mengalihkan koefisien tidak langsungnya yaitu $\mathrm{p} 4(0,122) \times \mathrm{p} 3(0,338)=0,041$. Adapun total pengaruh green perceived risk ke green repurchase intention $=(-0,044)+(0,041)=-0,003$.

\section{Pembahasan}

\section{Hipotesis 1 (green perceived value berpengaruh positif dan signifikan terhadap green repurchase intention)}

Berdasarkan hasil penelitian yang telah dilakukan bahwa green perceived value berpengaruh positif dan signifikan terhadap green repurchase intention hal tersebut diketahui dari hasil Uji t yang memiliki $p$-value $<(\alpha)$. Sedangkan, nilai $t_{\text {hitung }}>\mathrm{t}_{\text {tabel. }}$. Berdasarkan hasil tersebut berarti hipotesis yang menyatakan bahwa green perceived value berpengaruh positif dan signifikan terhadap green repurchase intention dinyatakan diterima. Artinya bahwa 
Sebuah produk dapat mengantarkan nilai kepada konsumen dengan menawarkan manfaat pembeda dari produk lain. Sebagai pembeda perusahaan memasukkan nilai lingkungan dalam suatu produk untuk menarik perhatian konsumen yang peka terhadap perubahan lingkungan saat ini. Semakin besar manfaat atau nilai produk yang diterima dan dirasakan konsumen, maka akan membentuk suatu signal minat beli ulang yang kuat dalam diri konsumen. Oleh karena itu upaya untuk mempertahankan green perceived value konsumen, Pertamina perlu menanamkan informasi lebih banyak lagi mengenai keunggulan produk ramah lingkungan serta mengajak konsumen yang telah sadar akan kepedulian lingkungan untuk ikut berkontribusi mengkampanyekan hal serupa. Perusahaan juga perlu memastikan nilai lingkungan yang dibawa produk diterima baik oleh konsumen. Semakin tinggi green perceived value yang diterima konsumen, maka semakin besar pula keinginan konsumen untuk melakukan pembelian ulang. Penelitian (Dewi dan Rastini, 2016) serta (Lam et al., 2016) menunjukkan hal yang sama dimana green perceived value berpengaruh positif dan signifikan terhadap green repurchase intention.

\section{Hipotesis 2 (green perceived risk berpengaruh negatif dan signifikan terhadap green repurchase intention)}

Berdasarkan hasil penelitian yang telah dilakukan bahwa green perceived risk berpengaruh negatif dan tidak signifikan terhadap green repurchase intention hal tersebut diketahui dari hasil uji t yang memiliki nilai $p$-value $($ sig.) $>(\alpha)$. Sedangkan, nilai thitung < $t_{\text {tabel. }}$ Maka, hipotesis yang menyatakan bahwa green perceived risk berpengaruh negatif secara signifikan terhadap green repurchase intention dinyatakan ditolak. Artinya green perceived risk mempunyai hubungan negatif dengan green repurchase intention. Hubungan negatif antara green perceived risk dengan green repurchase intention menunjukkan bahwa setiap kenaikan resiko hijau akan berpengaruh pada penurunan minat beli kembali, tetapi pengaruhnya kecil. Sehingga dari sudut pandang konsumen beranggapan bahwa ketika green perceived risk adri sebuah produk terlalu tinggi pada kerusakan lingkungan akan menyebabkan penurunan pada green repurchase intention. Begitupun sebaliknya penurunan dari green perceived risk akan berpengaruh pada kenaikan green repurchase intention. Penelitian ini tidak sejalan dengan penelitian (Dewi dan Rastini, 2016) yang menunjukkan bahwa green perceived risk berpengaruh negatif dan signifikan terhadap green repurchase intention.

\section{Hipotesis 3 (green trust berpengaruh positif dan signifikan terhadap green repurchase intention)}

Berdasarkan hasil penelitian yang telah dilakukan bahwa green trust berpengaruh positif dan signifikan terhadap green repurchase intention hal tersebut diketahui dari hasil Uji $t$ yang memiliki $p$-value (sig.) $<\alpha$. Sedangkan, nilai $t_{\text {hitung }}>t_{\text {tabel }}$. Berdasarkan hasil tersebut berarti hipotesis yang menyatakan bahwa green trust berpengaruh positif dan signifikan terhadap green repurchase intention diterima. Hal ini berarti bahwa Semakin kuat kredibilitas suatu merek terhadap image yang mengedepankan faktor ramah lingkungan tertanam baik di benak konsumen akan membantu konsumen mengurangi kebingunan dalam membeli produk dan lebih memilih merek yang sudah dipercayainya sesuai dengan apa yang dipersepsikan. Green trust adalah kesediaan menggunakan produk terpercaya yang memiliki dampak positif bagi lingkungan. BBM jenis pertalite dapat meningkatkan kepercayaan konsumen dengan menjaga reputasinya untuk tidak mencemari lingkungan, menjaga harapan konsumen untuk terus berkomitmen dan berkontribusi menjaga kelestarian lingkungan. Hal ini dapat diwujudkan secara nyata dengan inovasi pertamina dalam menambahkan bahan ecosave pada 
pertalite untuk menjaga kemurnian dan membuat mesin menjadi bersih yang dapat menambah kepercayaan konsumen. Penelitian ini sejalan dengan penelitian yang dilakukan oleh (Dewi dan Rastini, 2016) dan (Lam et al., 2016) menunjukkan bahwa green trust berpengaruh positif dan signifikan terhadap green repurchase intention.

\section{Hipotesis 4 (green perceived value Berpengaruh positif dan signifikan terhadap green trust)}

Berdasarkan hasil penelitian yang telah dilakukan bahwa green perceived value berpengaruh positif dan signifikan terhadap green trust hal tersebut diketahui dari hasil Uji t yang memiliki nilai signifikasi $<\alpha$ dan nilai $t_{\text {hitung }}>\mathrm{t}_{\text {tabel. }}$. Berdasarkan hasil tersebut berarti hipotesis yang menyatakan bahwa green perceived value berpengaruh positif dan signifikan terhadap green trust diterima. Apabila, green perceived value naik maka green trust juga naik. Semakin besar nilai lingkungan pada BBM jenis pertalite yang dirasakan konsumen maka akan mengurangi perasaan ragu-ragu mereka akan produk tersebut sehingga meningkatlah kepercayaan akan BBM jenis pertalite. Pertamina perlu meningkatkan nilai ramah lingkungan dari BBM jenis pertalite untuk meningkatkan kepercayaan konsumen. Penelitian dari (Chen dan Chang, 2013); (Dewi dan Rastini, 2016); (Lam et al., 2016) menunjukkan hal serupa bahwa green perceived value berpengaruh positif dan signifikan terhadap green trust.

\section{Hipotesis 5 (green perceived risk Berpengaruh negatif dan signifikan terhadap green trust)}

Berdasarkan hasil penelitian yang telah dilakukan bahwa green perceived risk berpengaruh positif dan tidak signifikan terhadap green trust hal tersebut diketahui dari hasil Uji t yang memiliki nilai $p$-value $>\alpha$. Sedangkan, nilai $t_{\text {hitung }}<t_{\text {tabel. }}$. Berdasarkan hasil tersebut berarti hipotesis yang menyatakan bahwa green perceived risk berpengaruh negatif dan signifikan terhadap green trust ditolak. Artinya variabel green perceived risk tidak berpengaruh negatif terhadap green trust. Oleh karena itu dapat disimpulkan bahwa green perceived risk diduga terdapat hubungan negatif terhadap green trust tidak terbukti kebenaranya dan hasil Penelitian ini tidak sejalan dengan penelitian yang di lakukan oleh (Chen dan Chang, 2012) dan (Dewi dan Rastini, 2016) yang menunjukkan bahwa green perceived risk berpengaruh negatif dan signifikan terhadap green trust. konsumen menganggap resiko yang ditimbulkan dari BBM jenis pertalite terhadap lingkungan masih rendah, namun hal tersebut belum cukup untuk mempengaruhi minat beli kembali konsumen atas BBM jenis pertalite. Konsumen BBM jenis pertalite lebih cenderung mengkhawatirkan faktor ekonomis seperti harga dibandingkan dengan kesadaran akan lingkungan.

\section{Hipotesis 6 (green trust mampu memediasi pengaruh green perceived value terhadap green repurchase intention)}

Berdasarkan hasil analisis jalur menunjukkan bahwa green trust mampu memediasi pengaruh green perceived value terhadap green repurchase intention pada konsumen masyarakat kota ternate yang menggunakan BBM jenis pertalite pada kendaraan bermotor, dengan nilai $0,221(22,1 \%)$. Artinya hipotesis yang menyatakan green trust mampu memediasi pengaruh green perceived value terhadap green repurchase intention dinyatakan diterima. Hal tersebut dikarenakan semakin banyaknya informasi yang didapat oleh konsumen mengenai manfaat suatu produk akan menimbulkan kepercayaan terhadap produk tersebut, dan kepercayaan tersebut akan dapat mempengaruhi perilaku pembelian kembali konsumen pada produk tersebut. Semakin besar kepercayaan konsumen terhadap manfaat 
suatu produk, maka akan semakin besar juga peluang konsumen tersebut akan melakukan suatu perilaku pembelian kembali pada suatu produk. Penelitian (Dewi dan Rastini, 2016) serta (Lam et al., 2016) menunjukkan hasil yang sama yaitu green trust secara signifikan memediasi pengaruh green perceived value terhadap green repurchase intention.

\section{Hipotesis 7 (green trust mampu memediasi pengaruh green perceived risk terhadap green repurchase intention)}

Berdasarkan hasil analisis jalur menunjukkan bahwa green trust mampu memediasi pengaruh green perceived risk terhadap green repurchase intention dengan nilai 0,041 $(4,1 \%)$. Artinya hipotesis yang menyatakan green trust mampu memediasi pengaruh green perceived risk terhadap green repurchase intention dinyatakan diterima. Artinya green trust mampu memediasi green perceived risk terhadap green repurchase intention. Hal ini berarti bahwa persepsi risiko memiliki pengaruh pada niat pembelian ulang kembali melalui kepercayaan. semakin tinggi persepsi resiko yang dirasakan oleh konsumen, maka semakin mengurangi kepercayaan dan akan menurunkan minat pembelian ulang pada suatu produk. Sebaliknya semakin rendah persepsi resiko, maka kepercayaan akan bertambah dan akan meningkatkan niat pembelian ulang green produk. Penelitian ini tidak sejalan dengan penelitian yang dilakukan oleh (Dewi dan Rastini, 2016) bahwa green trust secara signifikan memediasi pengaruh green perceived risk terhadap green repurchase intention.

\section{Kesimpulan}

Berdasarkan hasil analisis deskriptif dan analisis statistik serta pembahasan dalam penelitian ini, maka dapat diambil kesimpulan Berdasarkan uji hipotesis yang telah dilakukan menggunakan uji t dan uji pengaruh mediasi (uji jalur dan sobel). Hasil uji t menunjukkan bahwa green perceived value berpengaruh positif dan signifikan terhadap green trust dan green repurchase intention, green perceived risk berpengaruh positif dan tidak signifikan terhadap green trust, green perceived risk berpengaruh negatif dan tidak signifikan terhadap green repurchase intention pada BBM jenis pertalite. Kemudian Terdapat pengaruh positif dan signifikan green trust terhadap green repurchase intention. Hasil lainya menunjukan bahwa green trust mampu memediasi pengaruh green perceived value dengan baik pada hubungannya dengan green repurchase intention. green trust mampu memediasi pengaruh green perceived risk terhadap green repurchase intention.

\section{Daftar Pustaka}

Arikunto, S. (2006). Metodelogi penelitian. Bina Aksara.

Chang, H. H., dan Chen, S. W. (2008). The impact of online store environment cues on purchase intention: Trust and perceived risk as a mediator. Online Information Review, 32(6), 818-841. https://doi.org/10.1108/14684520810923953

Chen, Y. S. (2010). The drivers of green brand equity: Green brand image, green satisfaction, and green trust. Journal of Business Ethics, 93(2), 307-319. https://doi.org/10.1007/s10551-009-0223-9

Chen, Y. S. (2013). Towards green loyalty: Driving from green perceived value, green satisfaction, and green trust. Sustainable Development, 21(5), 294-308. https://doi.org/10.1002/sd.500

Chen, Y. S., dan Chang, C. H. (2012). Enhance green purchase intentions: The roles of green perceived value, green perceived risk, and green trust. Management Decision, 50(3), 502-520. https://doi.org/10.1108/00251741211216250 
Chen, Y. S., dan Chang, C. H. (2013). Towards green trust: The influences of green perceived quality, green perceived risk, and green satisfaction. Management Decision, 51(1), 63-82. https://doi.org/10.1108/00251741311291319

Chen, Y. S., Lin, C. Y., dan Weng, C. S. (2015). The influence of environmental friendliness on green trust: The mediation effects of green satisfaction and green perceived quality. Sustainability (Switzerland), 7(8), 10135-10152. https://doi.org/10.3390/su70810135

Dewi, S., dan Rastini, N. (2016). Peran Green Trust Memediasi Green Perceived Value Dan Green Perceived Risk Terhadap Green Repurchase Intention. E-Jurnal Manajemen Universitas Udayana, 5(12), 254866.

Ganesan, S. (1994). Determinants of Long-Term Orientation in Buyer-Seller Relationships. Journal of Marketing, 58(2), 1-19.

Ghozali, I. (2013). Aplikasi Analisis Multivariate dengan Program IBM SPSS 21. Badan Peneribit Universitas Diponegoro.

Hawkins, D. I., dan Mothershaugh, D. L. (2010). Consumer Behavior Building Marketing Strategy. McGrawHill.

https://www.google.co.id/amp/s/m.bisnis.com/amp/read/20190114/415/878359/kota-ternatepemakai-pertalite-tertinggi-di-maluku-utara (diakses pada 22 November 2020 pukul 11:12 WIT)

https://www.google.co.id/amp/s/beritagar.id/artikel-amp/gaya-hidup/ingin-udara-segarpergilah-ke-maluku-utara (diakses pada 22 November 2020 pukul 11:20 WIT)

https://www.kompas.com/skola/read/2020/01/13/200000969/perbedaan-pertamax-pertalitedan-premium?amp=1\&page $=2$ (diakses pada 22 November 2020 pukul 11:27 WIT)

Kim, C., Zhao, W., danYang, K. H. (2008). An empirical study on the integrated framework of e-CRM in online shopping: Evaluating the relationships among perceived value, satisfaction, and trust based on customers' perspectives. Journal of Electronic Commerce in Organizations, 6(3), 1-19. https://doi.org/10.4018/jeco.2008070101

Lacey, R., dan Morgan, R. M. (2008). Customer advocacy and the impact of B2B loyalty programs. Journal of Business \& Industrial Marketing, 24(1), 3-13. https://doi.org/10.1108/08858620910923658

Lam, A. Y. C., Lau, M. M., dan Cheung, R. (2016). Modelling the Relationship among Green Perceived Value, Green Trust, Satisfaction, and Repurchase Intention of Green Products. Contemporary Management Research, 12(1), 47-60. https://doi.org/10.7903/cmr.13842

Luis, J. B., dan Pramudana, K. A. S. (2017). PENGARUH GREEN PERCEIVED QUALITY, GREEN SATISFACTION DAN GREEN PERCEIVED RISK TERHADAP GREEN TRUST Fakultas Ekonomi dan Bisnis Universitas Udayana ( Unud ), Bali, Indonesia Masalah-masalah lingkungan sering terdengar di masyarakat misalnya pemanasan glo. 6(3), 1425-1451.

Polonsky, M. J. (1994). An Introduction To Green Marketing. Electronic Green Journal, 1(2). https://doi.org/10.5070/g31210177

Pratama, M. A. (2014). Pengaruh Green Perceived Value, Green Perceived Risk Dan Green Trust Terhadap Green Purchase Intention Lampu Philips LED di Surabaya M. Ashar Pratama. Jurnal Ilmiah Mahasiswa Universitas Surabaya, 3(1), 1-20.

Rahardjo, F. A. (2015). The roles of green perceived value, green perceived risk, and green trust towards green purchase intention of inverter air conditioner in Surabaya. IBuss Management, 3(2), 252-260.

Rizwan, M., Mahmood, U., Siddiqui, H., dan Tahir, A. (2014). An Empirical Study about Green Purchase Intentions. Journal of Sociological Research, 5(1), 290-305. https://doi.org/10.5296/jsr.v5i1.6567 
Saputro, N. R. (2013). ( Studi Kasus Pada Konsumen TV LCD dan LED Merek JurusanManajemenFakultasEkonomi UniversitasSebelasMaret Surakarta.

Sugiyono. (2015). Metode Penelitian Manajemen. Penerbit Alfabeta.

Waskito, J. (2015). Upaya Meningkatkan Niat Pembelian Produk Ramah Lingkungan Melalui Nilai, Risiko, dan Kepercayaan Terhadap Produk Hijau. Etikonomi, 14(1), 1-16. https://doi.org/10.15408/etk.v14i1.2259

Wulansari, C., dan Sri Suprapti, N. (2015). Efek Mediasi Kepuasan Dalam Hubungan Antara Persepsi Risiko Dengan Kepercayaan Produk Kosmetik Hijau Merek the Face Shop. EJurnal Manajemen Universitas Udayana, 4(4), 255065.

Zeithaml, V. A. (1988). Consumer Perceptions Of Price, Quality, And Value : A Means-. 